\title{
Powdery Mildew on Watermelon in Florida ${ }^{1}$
}

\author{
Pamela D. Roberts, Mathews Paret, and Nicholas Dufault ${ }^{2}$
}

\section{Introduction}

Powdery mildew on watermelon has been present in the southeastern US for the past few decades. However, the disease has become more problematic in Florida within the past few years. In spring 2018 in South Florida, powdery mildew outbreaks on vines and fruit were more widespread and severe than the previous five years. Watermelon in north and central Florida has been experiencing increasing epidemics of this disease in the past 3-4 years, while the disease has been seen in isolated cases since 2011. Powdery mildew can reduce yields by reducing the size, quality of fruit, and decreasing the number of times that the crop can be harvested. Powdery mildew can occur on fruit but usually the biggest impact is when the foliage is heavily infected and the fruit loses foliar protection that can lead to sunburn. In some cases, up to $34 \%$ yield reduction has been reported in other watermelon production areas (Keinath and Dubose 2004).

\section{Causal Organism}

The fungus Podosphaera xanthii (previously known as Sphaerotheca fuliginea) was identified as the causal agent on watermelon fruit from southwest Florida (Kousik et al. 2011) and additional cucurbits throughout Florida (Maia 2012). It is an obligate biotroph, meaning that it can only survive on living host tissue. Chains of conidia (Figure 1), fungal propagules that allow the pathogen to reproduce, are produced and are easily wind-blown to new infection sites.

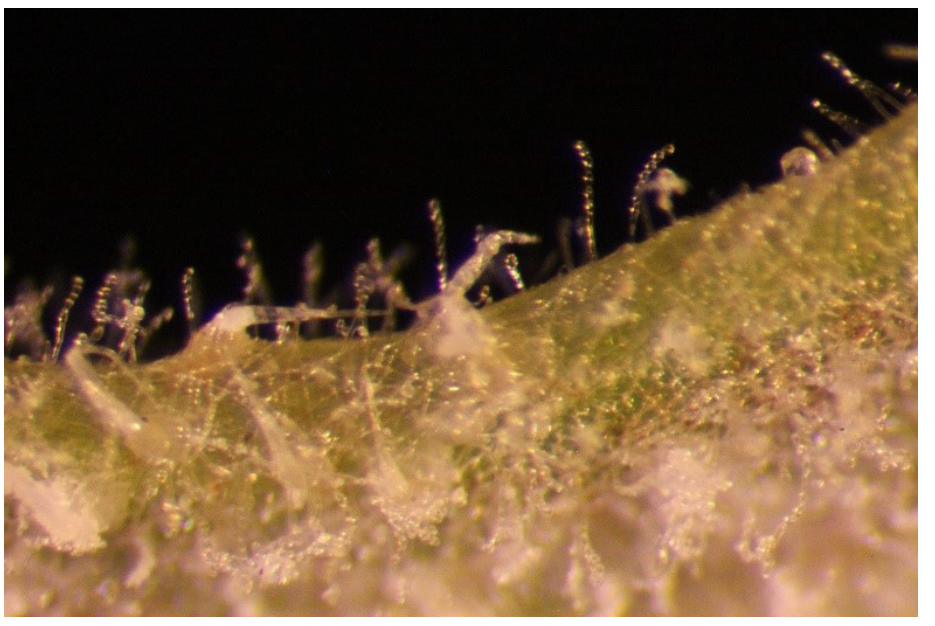

Figure 1. Chains of conidia of powdery mildew fungus (Podosphaera xanthii) on watermelon leaf surface.

Credits: Katherine Hendricks

\section{Signs and Symptoms}

Initial symptoms of powdery mildew appear on the older leaves with a reddish-brown, bronzed appearance. At this point, other problems such as viral infections, chemical phytotoxicity, and certain nutrient deficiencies can cause similar symptoms; therefore, microscopic examination may be needed to observe the causal agent. As the disease progresses, the typical white powdery fungal growth (mycelia and conidia) may occur on petioles and leaves (Figure 2). The fruit can also exhibit white, powdery patches on the rind surface (Figure 3). The signs (i.e., white powdery patches) are relatively easy to identify and are diagnostic for this disease.

1. This document is PP342, one of a series of the Plant Pathology Department, UF/IFAS Extension. Original publication date January 2019. Visit the EDIS website at https://edis.ifas.ufl.edu for the currently supported version of this publication.

2. Pamela Roberts, professor; Mathews Paret, assistant professor; and Nicholas Dufault, associate professor, Department of Plant Pathology; UF/IFAS Extension, Gainesville, FL 32611.

The Institute of Food and Agricultural Sciences (IFAS) is an Equal Opportunity Institution authorized to provide research, educational information and other services only to individuals and institutions that function with non-discrimination with respect to race, creed, color, religion, age, disability, sex, sexual orientation, marital status, national origin, political opinions or affiliations. For more information on obtaining other UF/IFAS Extension publications, contact your county's UF/IFAS Extension office. 


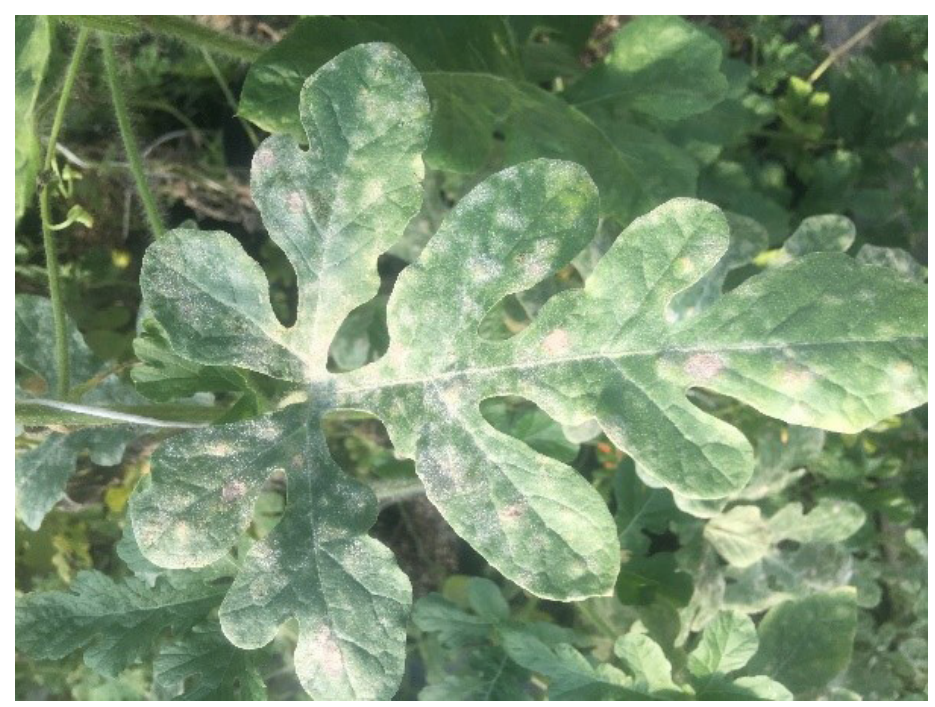

Figure 2. Foliar symptoms and signs of powdery mildew on the surface of watermelon leaf.

Credits: Randy Johnson

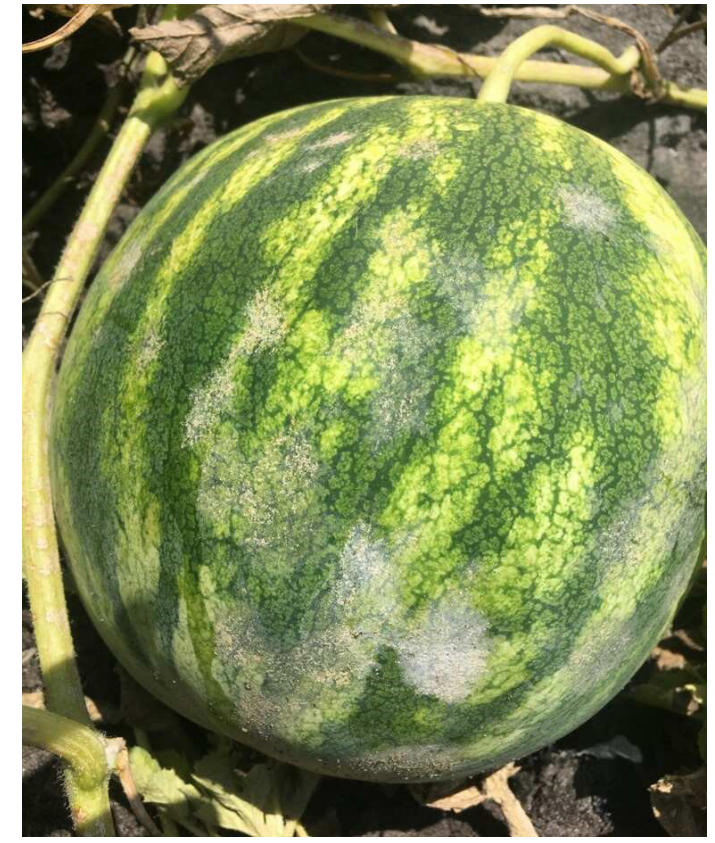

Figure 3. Signs of powdery mildew on the watermelon rind surface. Credits: Kevin Short

\section{Disease Cycle}

The fungus can survive between seasons on weed hosts and sometimes in greenhouses. It can also be naturally transported long distances ( $>60$ miles) by wind from warmer tropical areas. As mentioned above, conidia (the primary infective unit of this pathogen) form in chains on the host tissue. These chains break apart and are dispersed by wind or spread by worker/plant movement in the fields. Conidia landing on the watermelon plant will germinate and infect the various plant tissues (e.g. leaves and fruits). The infections typically occur when temperatures are moderate $\left(68^{\circ} \mathrm{F}\right.$ to $\left.80^{\circ} \mathrm{F}\right)$ and humidity is high $(>50 \%)$, and new conidia can be produced within a few days $(<5)$ under the favorable conditions (McGrath 2017). Because of this short development period, powdery mildew can spread quickly and rapidly ( $<20$ days) to cover the foliage and fruit.

\section{Management}

Disease management starts before the watermelons are even planted. Field sanitation by removal of weeds, such as citron watermelon, and volunteer plants that may harbor powdery mildew or other pathogens is recommended before and after planting. Unfortunately, no commercial watermelon cultivars have resistance to this disease; thus, early detection by frequent and thorough scouting of the fields is key to limiting the impact of this disease with chemical controls.

\section{Chemical Controls}

Fungicides can be effective in managing this pathogen, however, their efficacy is typically improved when applied before the epidemic reaches 10 to 25\% severity.See Chapter 7 of the 2018-2019, "Cucurbit Production" (http://edis. ifas.ufl.edu/cv123) for more information about chemical products available for disease control).

Although fungicide resistance to several active ingredients has been documented in many other production regions (McGrath 2001; McGrath and Sexton 2018), the state of the current fungal population's resistance to these materials in Florida is unknown.

The powdery mildew fungus is considered 'high risk' for becoming resistant to certain fungicides, therefore resistance management guidelines as outlined on individual fungicide labels should be followed. This includes rotation of fungicides with different modes of action and applying fungicides in tank mixtures. For further information about resistance management, contact your local UF/IFAS Extension office (http://sfyl.ifas.ufl.edu/find-your-local-office/).

\section{References}

Keinath, A. P. and V. B. Dubose. 2004. "Evaluation of fungicides for prevention and management of powdery mildew on watermelon." Crop Protection. 23: 35-42.

Kousik, C. S., R. S. Donahoo, C. G. Webster, W. W. Turechek, S. T. Adkins, and P. D. Roberts. 2011. "Outbreak of cucurbit powdery mildew on watermelon fruit caused by Podosphaera xanthii in Southwest Florida." Plant Disease. 95: 1586 
Maia, G. S. 2012. "Isolation, identification and characterization of cucurbit powdery mildew in North central Florida." Ph.D. Thesis. University of Florida.

McGrath, M. T. 2001. "Fungicide resistance in cucurbit powdery mildew: experiences and challenges." Plant

Disease. 85: 236-245.

McGrath, M. T. 2017. “Powdery Mildew.” In: Compendium of Cucurbit Diseases. Keinath, A.P., Wintermantel, W.M., and Zitter, T.A. eds. 62-64. St. Paul, MN: American Phytopathological Society.

McGrath, M. T. and Z. F. Sexton. 2018. "Poor control of cucurbit powdery mildew associated with first detection of resistance to cyflufenamid in the causal agent, Podosphaera xanthii, in the United States." Plant Health Progress 19:

222-223. 